\title{
MỘT SỐ KÊTT QUẢ NGHIÊN CÚU BƯỚC ĐẦU VỀ ĐộNG LỰC TRẦM TÍCH LƠ LƯNG TRONG MÙA LŨ TẠI VÙNG BIẾN VEN BỜ CỬA SÔNG HẬU
}

\author{
Nguyễn Ngọc Tiến ${ }^{1 *}$, Nguyễn Trung Thành ${ }^{1}$, Vũ Hải Đăng ${ }^{1}$, Vũ Duy Vĩnh ${ }^{2}$ \\ ${ }^{1}$ Viện Địa chất và Địa vật lý biển-Viện Hàn lâm Khoa học và Công nghệ Việt Nam \\ ${ }^{2}$ Viện Tài nguyên và Mồi trường biển-Viện Hàn lâm Khoa học và Công nghệ Việt Nam \\ "E-mail: nntien@imgg.vast.vn
}

Ngày nhận bài: 29-6-2015

\begin{abstract}
TÓM TĂT: Các mối tuơng tác biển - đất liền trong vùng ven bờ bị chi phối chủ yếu bởi các quá trình thủy động lục nhu sóng, dòng chảy, lưu luợng nước sông, thủy triều trong đó thủy triều đóng vai trò quan trọng. Tại các khu vực có lưu lượng phù sa lớn như vùng ven biển sông Hậu, các quá trình này càng trở nên rõ rệt khi phân tích tù số liệu khảo sát trong thời kỳ mùa lũ (tháng 9) thuộc chuoong trình hơp tác khoa hoc và công nghệ giữa Việt Nam và Hoa Kỳ (2013 - 2015) và đề tài độc lập mã số VAST-ĐLT.06/15-16 (2015 - 2016). Trong chuyến khảo sát này, muc đích là điều tra sự lắng đọng và phân bố theo không gian, thời gian của hàm luợng trầm tích lơ lửng. Ngoài ra, chúng tôi còn khảo sát ảnh hưởng của dòng triều trong mối tương quan với hàm lương trầm tích lo lưng. Độ muối (đơn vị PSU - Practical Salinity Unit), hàm luợng trầm tích lơ lưng (đơn vị đo NTU Nephelometric Turbidity Units) được đo bằng thiết bị Compac-CTD (Depth temperature conductivity chlorophyll turbidity), và thiết bi đo độ đục OBS-3A (Turbidity and Temperature Monitoring System). Kết quả nghiên cứu cho thấy hàm lượng trầm tích lo lửng tuơng quan với vận tốc dòng chảy. Tốc độ dòng chảy khi triều lên đến $60 \mathrm{~cm} / \mathrm{s}$ ở lớp mặt và $40 \mathrm{~cm} / \mathrm{s}$ ở đáy tạo nên sự tăng nồng độ trầm tích lo lưng trong cột nước ở tầng đáy 24 NTU và 8 NTU tại tầng mặt. Trong pha triều lên, quá trình vận chuyển và lắng đọng trầm tích lơ lửng bị chi phối bởi dòng triều dài hơn so với mùa khô. Điều này cho thấy sụ bất đối xứng của elip thủy triều và dẫn đến sự lắng đọng trầm tích lo lưng trong các mùa là khác nhau. Tù kết quả phân tích có thể thấy vùng biển ven bò̀ cưa sông Hậu, hàm luợng trầm tích lo lủng chịu sư chi phối bởi dòng chảy triều và thủy triều là rất lớn, do đó quá trình lan truyền, xáo trộn nước sông và biển có sư khác biệt đáng kể trong các điều kiện triều và điều kiện mùa.
\end{abstract}

Tù khóa: Trầm tích lơ lưng, độ muối, động lực trầm tích, sông Hậu.

\section{MỞ ĐẦU}

Vùng cửa sông là vùng có hệ sinh thái đặc thù, là nơi giao thoa, tương tác giữa môi trường lục địa và biển, là nơi chứa nhiêuu tiềm năng to lớn về tài nguyên thiên nhiên và cũng là nơi xảy ra nhiều tai biến thiên nhiên với những hiểm họa khó lường. Nhận thức được tầm quan trọng của vùng cửa sông ven biển trong vấn đề phát triển kinh tế - xã hội, trên thế giới, đối với các quốc gia có đường bờ biển, nhận thức được điều này, các nhà quản lý, nghiên cứu khoa học đã có những công trình nghiên cứu, dự án nghiên cứu sâu về thủy động lực, môi trường biển nói chung và quá trình động lực trầm tích nói riêng. Việc nghiên cứu động lực trầm tích vùng cửa sông ven biển góp một phần thông tin quan trọng trong việc nghiên cứu quy luật biến 


\section{Một số kết quả nghiên cúu bước đầu về động ...}

động trầm tích vùng nghiên cứu. Tại hệ thống sông Mê Kông lưu lượng trầm tích tải ra hàng năm khoảng 160 triệu tấn. Trong số này, phần được giữ lại bồi tích cho vùng châu thổ hạ lưu chiếm khoảng $50 \%$, khoảng $10 \%$ lắng đọng ở vùng biển ven bờ cửa sông, còn lại $40 \%$ sẽ được vận chuyển dọc bờ đi nơi khác do các quá trình thủy động lực, xa nhất có thể tới $500 \mathrm{~km}$ $[1,2]$.

Đặc điểm thủy động lực vùng biển ven bờ cửa sông Hậu chịu ảnh hưởng mạnh mẽ bởi thủy triều Biển Đông với chế độ bán nhật triều không đều, thời gian triều lên kéo dài khoảng 6 giờ và thời gian triều xuống khoảng 7 giờ [3], biên độ mực nước lớn nhất trung bình tại trạm Mỹ Thanh khoảng 1,5 - 1,8 m (hình 1). Trong bài báo này chúng tôi công bố một số kết quả phân tích các đặc trưng thủy động lực trầm tích thu được từ đợt khảo sát tháng 9 năm 2014 (là tháng trong mùa lũ khi đo ảnh hưởng của gió mùa là không đáng kể) tại các trạm cố định và các trạm mặt rộng trên vùng biển ven bờ cửa sông Hậu.

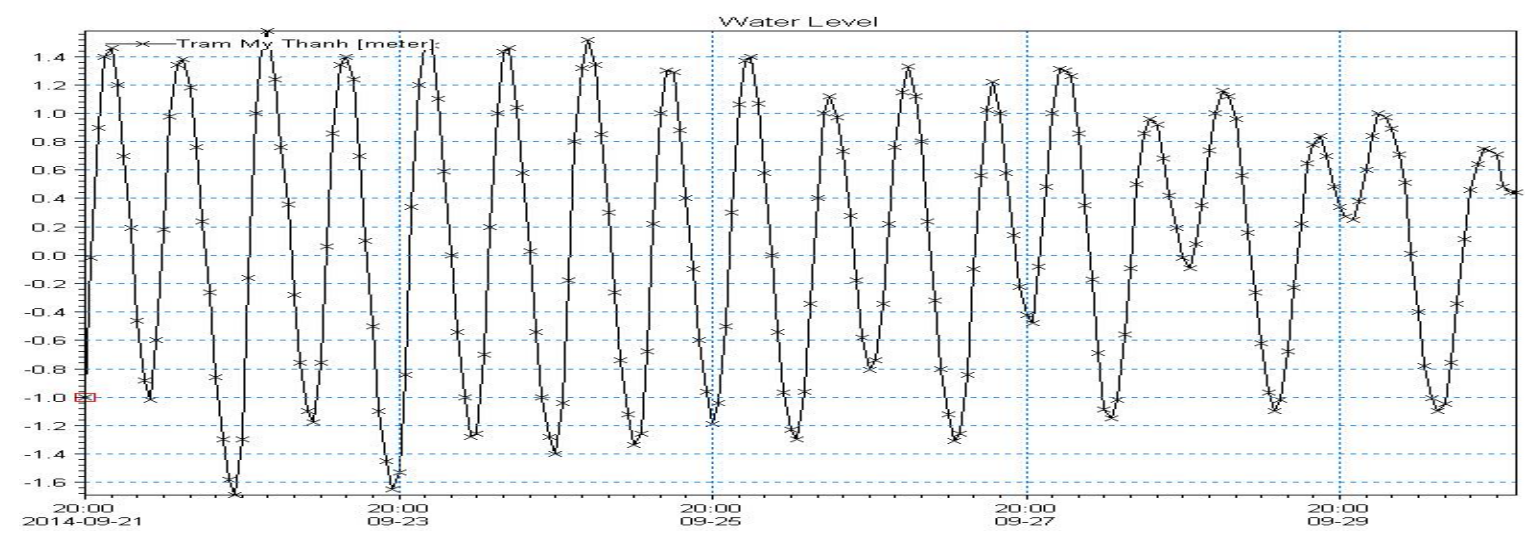

Hình 1. Biến trình mực nước tại trạm Mỹ Thanh

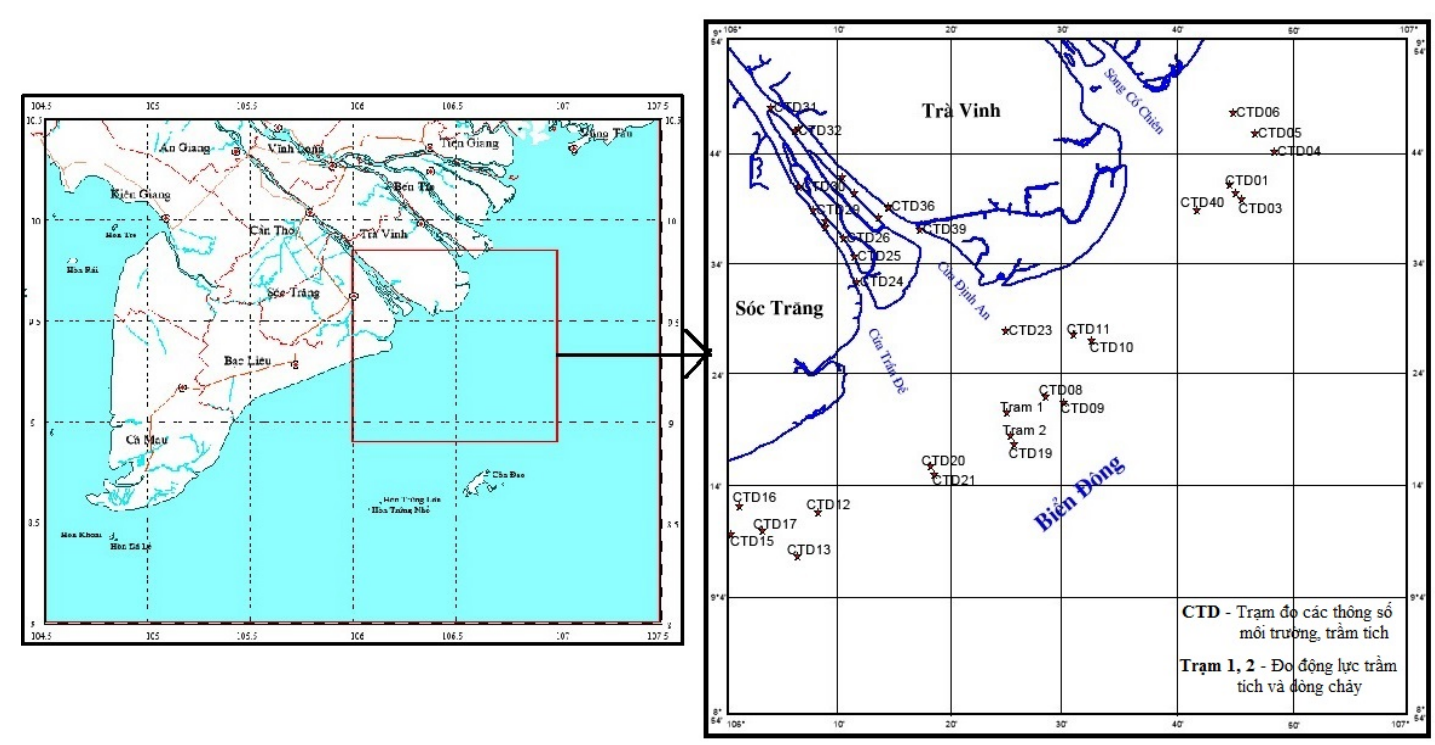

Hình 2. Khu vực nghiên cứu và điểm khảo sát

TÀI LIỆU VÀ PHƯƠNG PHÁP NGHIÊN CúU
Trong nghiên cứu này, các đặc trưng thủy động lực trầm tích lơ lửng tại cửa sông được 
phân tích từ số liệu đo đạc thuộc chương trình hợp tác khoa học và công nghệ giữa Việt Nam và Hoa Kỳ $(2013$ - 2015) và đề tài độc lập trẻ mã số VAST-ĐLT.06/(2015 - 2016) do Viện Địa chất và Địa vật lý biển chủ trì đã triển khai các đợt khảo sát thực địa trong năm 2013, 2014 và 2015 trên vùng biển ven bờ sông Hậu.

Theo đó chúng tôi đã sử dụng số liệu về độ muối, hàm lượng trầm tích lơ lửng được thu thập trong chuyên khảo sát vào mùa lũ năm 2014 tại 40 điểm theo không gian và thời gian (hình 2 ), kết quả thể hiện trong hình 3 đến hình 6. Chuyến khảo sát này kéo dài từ 25 tháng 9 đến ngày 3 tháng 10 năm 2014.

Tại hai trạm khảo sát liên tục 12 h ở độ sâu $8 \mathrm{~m}$ (trạm 1$)$ và $16 \mathrm{~m}$ (trạm 2 ) và cách nhau $5 \mathrm{~km}$ trên thềm châu thổ (hình 2). Trong thời gian đó, các dữ liệu độ muối, dao động mực nước và hàm lượng trầm tích lơ lửng được đo bằng thiết bị đo các yếu tố môi trường (CTD) và thiết bị đo độ đục (OBS-3A) hàng giờ.

\section{KẾT QUẢ VÀ THẢO LUẬN}

\section{Phân bố theo không gian của hàm lượng trầm tích lơ lửng}

Phân bố không gian là kết quả phân tích của số liệu thực đo từ 40 trạm mặt rộng được thả từ mặt xuống đáy trong chuỗi thời gian khác nhau, kết quả cho thấy:

Trong mùa lũ, phân bố trầm tích lơ lửng chủ yếu ở cửa sông ven biển tại độ sâu $2 \mathrm{~m}$ (hình 3b) đạt giá trị lớn nhất 190 NTU và giảm dần ra phía ngoài có độ sâu $20 \mathrm{~m}$ giá trị dao động từ 20 - 190 NTU, tại tầng mặt (hình 3a) giá trị dao động trong khoảng 20 - 120 NTU, hàm lượng phân bố giảm dần từ trong sông ra phần thềm ngập nước nơi có độ sâu $20 \mathrm{~m}$, tương tự tại tâng $5 \mathrm{~m}$ (hình $3 \mathrm{c}$ ) giá trị hàm lượng trầm tích lơ lửng dao động trong khoảng 10 - 109 NTU. Tại các độ sâu từ $10,15,20 \mathrm{~m}$ (hình $3 \mathrm{~d}, 3 \mathrm{e}, 3 \mathrm{~g}$ ) hàm lượng trầm tích lơ lửng dao động trong khoảng từ 2 NTU đến 20 NTU, chủ yếu phân bố ở phía ngoài cửa sông, nơi mà độ sâu dao động từ $10 \mathrm{~m}$ đến $20 \mathrm{~m}$ nước. Như vậy, có thể thấy rằng hàm lượng trầm tích lơ lứng tại các trạm cửa sông, trong sông rất cao so với trạm xa bờ. Tại các trạm có độ sâu từ $0 \mathrm{~m}$ đến $5 \mathrm{~m}$, hàm lượng trầm tích lơ lửng cực đại ở tầng giữa.

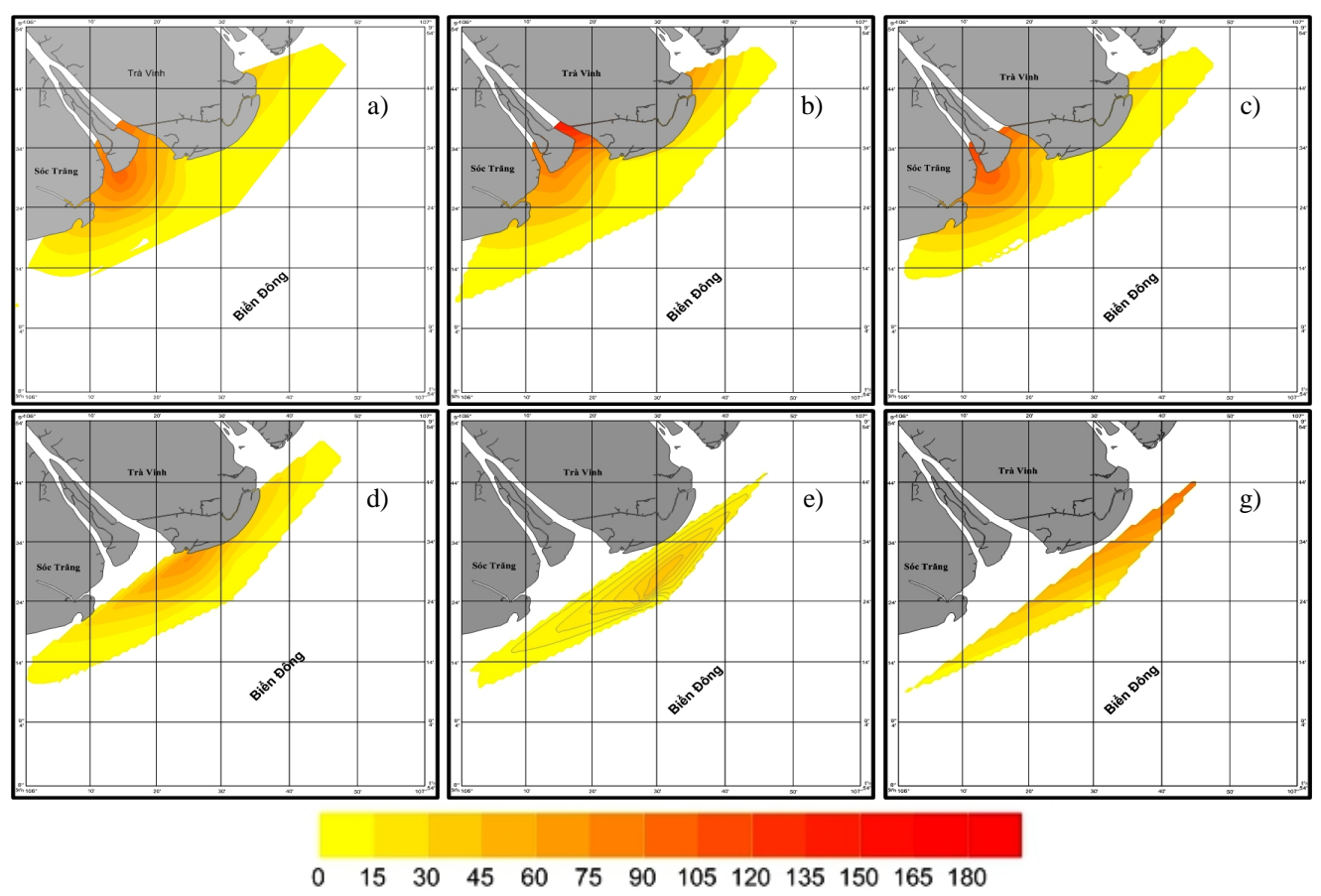

Hình 3. Phân bố không gian hàm lượng trầm tích lơ lửng tầng mặt đến $20 \mathrm{~m}$ nước a) tầng mặt; b) tầng $2 \mathrm{~m}$; c) tầng $5 \mathrm{~m}$; d) tầng $10 \mathrm{~m}$; e) tầng $15 \mathrm{~m} ; \mathrm{g}$ ) tầng $20 \mathrm{~m}$ 


\section{Một số kết quả nghiên cúu bước đầu về động ...}

Ảnh hưởng của dòng chảy triều đến phân bố hàm lượng trầm tích lơ lửng cho thấy rằng tại cửa Định An và Tranh Đề có khối nước với hàm lượng trầm tích lơ lửng cao lan tỏa ra xa bờ $30-50 \mathrm{~km}$ theo hướng đông nam nhưng bị uốn cong dần theo hướng tây nam ở phần phía nam khu vực nghiên cứu, trong khi ở phần phía bắc khối nước đục bị ép sát về phía bờ. Hàm lượng trầm tích lơ lửng cao nhất là vùng cửa sông Cổ Chiên và Định An ( $\approx 200$ NTU).

\section{Phân bố theo thời gian hàm lưọng trầm tích lơ lửng}

Biến động phân bố theo thời gian từ mặt tới đáy của độ muối và độ đục (trầm tích lơ lửng) phản ánh một cách sinh động hệ quả tác động của chế độ thủy động lực lên đặc điểm môi trường nước. Biến trình của độ muối trong các lớp nước mặt, giữa và đáy (hình $4 \mathrm{a}, 4 \mathrm{~b}$ ) cho thấy biên độ dao động của độ muối tăng theo sự gia tăng của độ cao triều với chênh lệch cực đại gần $20 \%$ đối với tầng mặt và $25 \%$ đối với tầng đáy.

Vào kỳ triều kiệt, do vận tốc dòng chảy không lớn nên đã xuất hiện sự phân tầng độ muối đáng kể trong toàn cột nước. Trong lớp gần mặt nước từ sông đổ ra có độ muối thấp giá trị dao động trong khoảng 8 - 20 PSU ít bị xáo trộn với lớp nước cửa sông có độ muối cao trên $22 \mathrm{PSU}$ nằm phía dưới thậm chí còn chịu ảnh hưởng khuếch tán từ dưới lên duy trì độ muối cao ở tầng giữa và tầng đáy vào khoảng 26 - 32 PSU.

Vào kỳ triều cường, quá trình xáo trộn mạnh đến sát đáy vào pha triều rút đã làm cho độ muối giảm đến giá trị cực tiểu do nước sông chiếm lĩnh. Tuy nhiên, trong khi triều cường đạt đỉnh từ 14 - $16 \mathrm{~h}$, lớp nước nhạt trên mặt hầu như biến mất nhường chỗ cho lớp nước biển với độ muối trên 30 PSU. Trên (hình $4 \mathrm{a}$, 4b) miêu tả các trường hợp phân bố đặc biệt của độ muối vừa nêu.
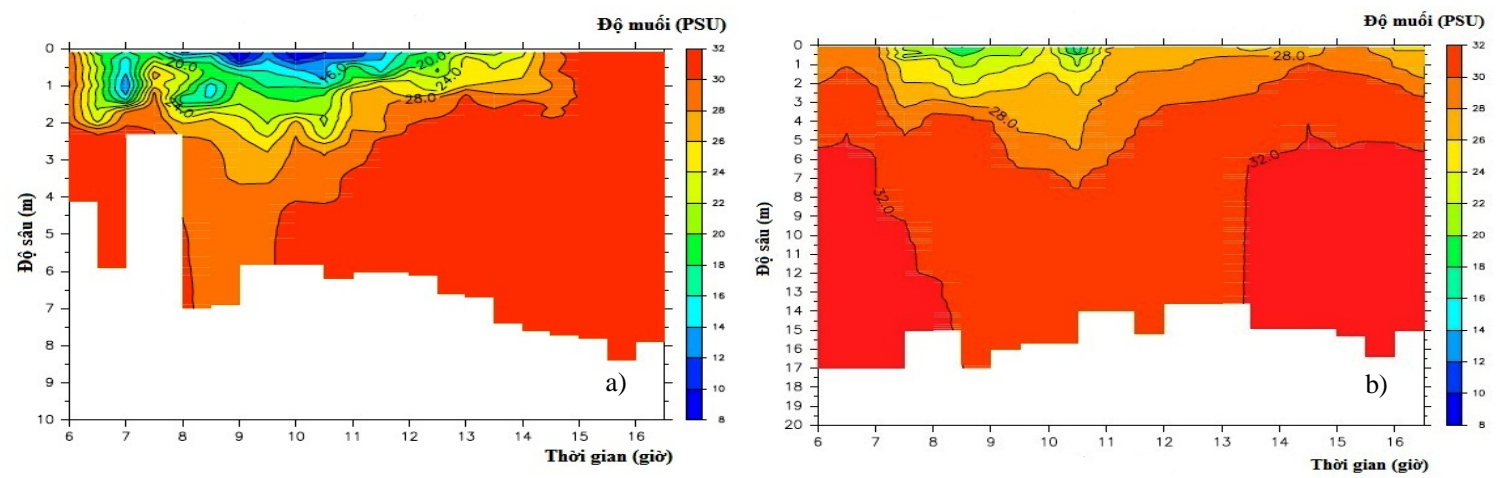

Hình 4. Biến động độ muối tại điểm khảo sát a) trạm 1, b) trạm 2
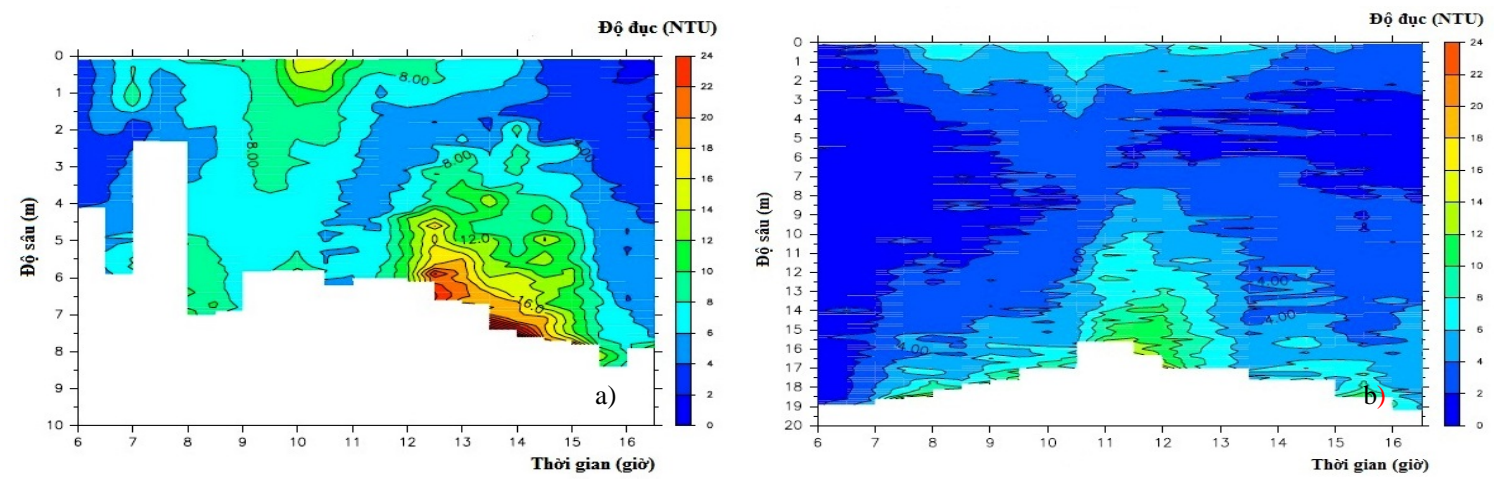

Hình 5. Biến trình trầm tích lơ lửng theo thời gian phân tích theo giá trị NTU tại điểm khảo sát a) trạm $1, \mathrm{~b}$ ) trạm 2 
Quá trình vận chuyển và khuếch tán các nguồn nước trao đổi qua cửa sông cũng được thể hiện rõ nét phân bố và biến trình của nồng độ trầm tích lơ lửng được biểu diễn thông qua độ đục (NTU).

Lớp nước sông có độ muối thấp 8 PSU và độ đục $(8$ - 24 NTU) thường chiềm lĩnh lớp nước mặt có độ dày đến $2 \mathrm{~m}$ trong pha triều rút thời gian từ $8-10$ giờ sáng (hình $5 \mathrm{a}$ ). Chúng có thể xáo trộn với nước từ phía biển đi vào có độ muối tương đối cao lớn hơn $20 \%$ và độ đục tương đối thấp, chiếm lĩnh phần lớp nước mặt. Quá trình khuếch tán hình thành nên lớp nước gần đáy có giá trị trung bình của độ muối khoảng 30 PSU và độ đục xấp xỉ khoảng 30 NTU trong pha triều cường, đây là hiện tượng tái lơ lửng của hàm lượng trầm tích lơ lửng tại tầng đáy trong pha triều lên ở trạm đo gần bờ. Trên hình $5 \mathrm{~b}$, hàm lượng độ đục cao ở lớp nước mặt và đáy dao động trong khoảng từ 10 20 PSU và thấp ở tầng giữa giá trị vào khoảng 2 - 4 PSU. Đây là hiện tượng xâm nhập của nước sông ra xa với hàm lượng độ đục nhỏ trên lớp nước mặt trong pha triều rút và hiện tượng tái lơ lửng khi pha triều lên ở tầng đáy tại trạm đo xa bờ.

\section{Ảnh hưởng của dòng triều đến hàm lượng trầm tích lơ lửng}
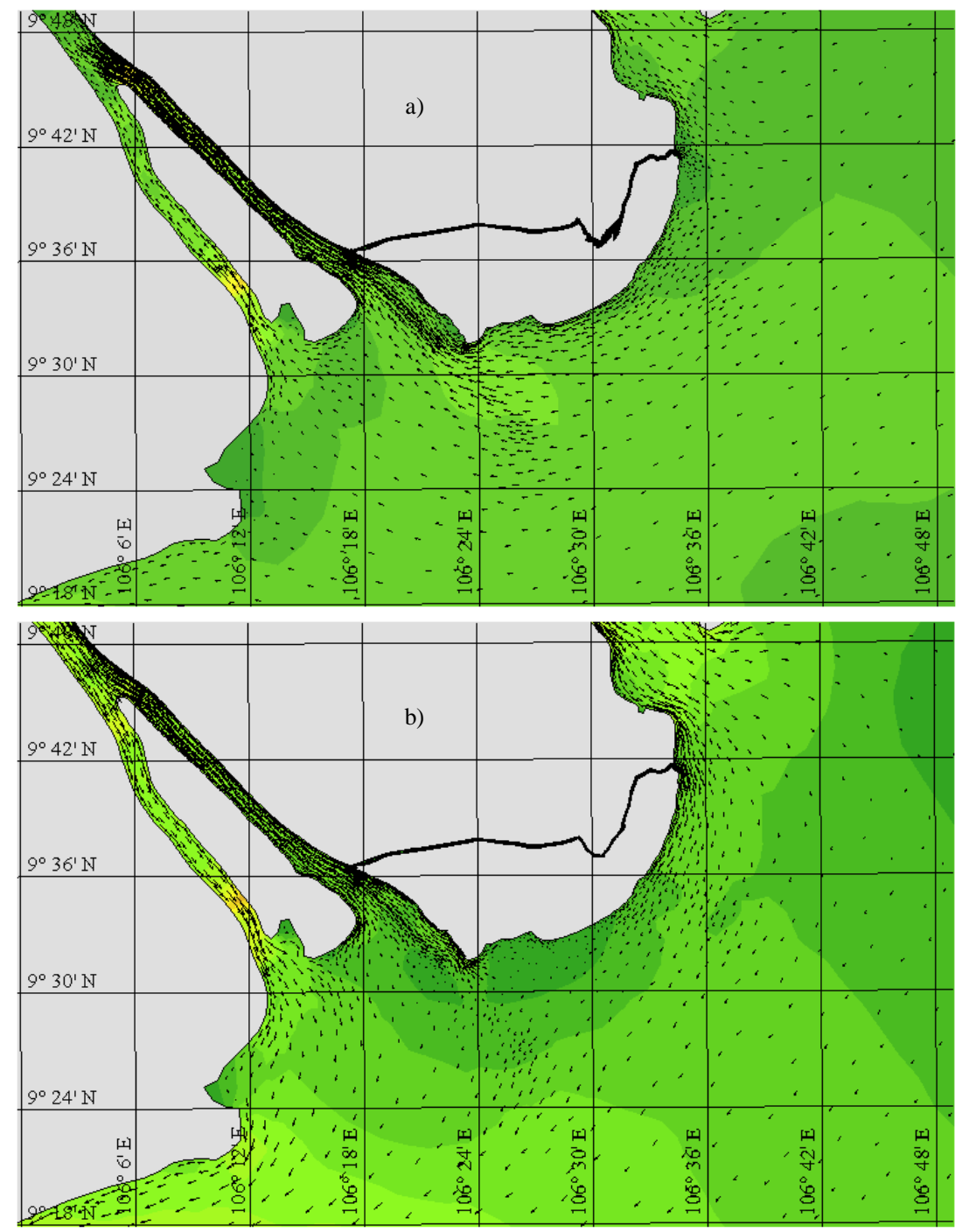

Hình 6. Phân bố tốc độ dòng chảy tại vùng nghiên cứu (a) triều lên, (b) triều xuống
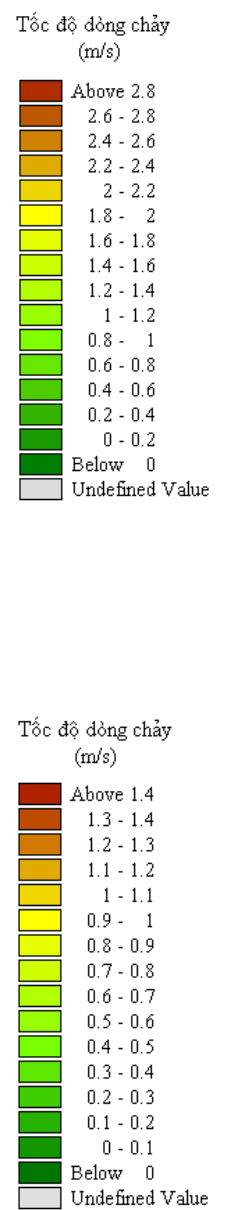
Kết quả mô phỏng từ mô hình cho thấy, trong mùa mưa tốc độ dòng chảy trung bình tầng mặt biến đổi trong khoảng $0,8-1 \mathrm{~m} / \mathrm{s}$, tốc độ dòng chảy cực đại tập trung ở khu vực các cửa sông với độ lớn đạt $1,2-2 \mathrm{~m} / \mathrm{s}$, tốc độ dòng chảy cực đại xuất hiện trong các pha triều xuống, khi dòng chảy sông kêt hợp dòng triều làm tốc độ dòng chảy lớn cực đại. Ở khu vực phía ngoài khơi, tốc độ dòng chảy trung bình dao động trong khoảng $0,3-0,4 \mathrm{~m} / \mathrm{s}$, hướng dòng chảy cũng ít phân tán hơn so với khu vực ven bờ. Ở vùng ngoài khơi, xu thế chung của tốc độ dòng chảy là tăng dần từ khu vực Côn Đảo xuống tới biên phía nam và tăng dần từ vùng biển Côn Đảo lên biên phía bắc của phạm vi tính toán. Trong thời kỳ triều lên, do sự tương tác của khối nước sông và khối nước biển, làm cho tốc độ dòng chảy ở khu vực cửa sông nhỏ hơn so với vùng phía ngoài khơi (hình 6) [5].

Quá trình vận chuyển và khuếch tán các nguồn nước trao đổi qua cửa sông cũng được thể hiện rõ nét phân bố và biến trình của nồng độ trầm tích lơ lửng được biểu diễn thông qua độ đục (NTU và phụ thuộc chặt chẽ vào chế độ thủy động lực trên khu vực, nguồn cung, ngoài ra còn phụ thuộc vào sự chênh lệch tỷ trọng giữa nước ngọt và nước mặn ... Vùng cửa sông ven bờ hệ thống sông Hậu có chế độ thủy triều phức tạp, biên độ triều lớn và tải lưu lượng nước sông biến đổi mạnh theo mùa. Do đó, nồng độ trầm tích lơ lửng có sự khác biệt theo mùa. Theo đó, trong mùa mưa do lưu lượng nước sông lớn kết hợp với đặc trưng thủy triều khu vực với biên độ khá cao, làm cho dòng vật chất ở trong sông đưa ra có điều kiện phát triển mạnh ra phía ngoài khơi, kết quả phân tích từ số liệu khảo sát ở trên đã có những kết luận cụ thể. Sự biến động hàm lượng trầm tích lơ lửng trong nước phụ thuộc nhiều nhất vào chế độ triều khu vực. Đây là khu vực có biên độ triều lớn, kết hợp với lưu lượng nước sông đồ ra làm cho dòng triều ở đây khá mạnh trong pha triều xuống gây tác động mạnh đến sự vận chuyển và phát tán của trầm tích lơ lửng ra phía ngoài khơi. Trong pha triều lên, do sự tương tác giữa khối nước biển và khối nước sồng, phạm vi ảnh hưởng của khối nước có hàm lượng trầm tích lơ lửng cao bị thu hẹp đáng kể so với pha triều xuống. Ngoài ra sóng ảnh hưởng chủ yếu đến sự phận bố của trầm tích lơ lửng.
Nó tạo ra sự tái lơ lửng của trầm tích [4]. Ảnh hưởng của sóng và dòng triều là đáng kể theo hai mùa gió đặc trưng. Trong mùa gió Tây Nam, dòng chảy song song với bờ theo hướng đông bắc chiếm tới $60 \%$ với vận tốc lớn nhất $70 \mathrm{~cm} / \mathrm{s}$, trong khi đó mùa gió Đông Bắc dòng chảy theo hướng tây nam chiếm tới $70 \%$ với vận tốc lớn nhất $60 \mathrm{~cm} / \mathrm{s}$ [5].

\section{KẾT LUẬN}

Kết quả phân tích số liệu khảo sát mùa lũ tháng 9 năm 2014 cho thấy các đặc trưng thủy động lực, độ muối và trầm tích lơ lửng vùng biển ven bờ cửa sông Hậu chịu ảnh hưởng quyết định bởi dòng chảy triều, trong đó quá trình lan truyền và xáo trộn nước sông và nước vùng cửa sông ven biển có sự khác biệt đáng kể trong các điều kiện triều cường và triều kiệt.

\section{Kết quả đã chứng minh:}

Sóng và dao động mực nước triều ở vùng biển này ảnh hưởng quan trọng đến đặc điểm phân bố hàm lượng trầm tích lơ lửng, chúng làm tăng cường hoặc hạn chế sự phát tán của hàm lượng trầm tích lơ lửng từ cửa sông ra ngoài biển, đồng thời tạo thành đới front giữa nước sông và biển vùng cửa sông. Trong pha triều xuống làm tăng cường sự phát tán của hàm lượng trầm tích lơ lửng từ lục địa ra phía ngoài biển trong khi đó trong pha triều lên làm tăng cường xáo trộn, khuếch tán hàm lượng trầm tích lơ lửng từ các tầng dưới lên các tẩng trên mặt, đồng thời vào thời điểm nước đứng hàm lượng trầm tích được tính tụ và lắng xuống đáy [6].

Xét trên phần châu thổ ngập nước sông Mê Kông, các elip triều của hợp phần chủ đạo M2 mở rộng về hướng đông bắc - tây nam [7]. Theo đó, các hạt vật chất tái lơ lửng được gia tốc theo hướng đông bắc trong pha triều xuống. Quanh vùng nước nông, từ pha triều xuống đên pha triều lên, các vector vận tốc thay đổi nhanh theo hướng tây nam và các vật chất lơ lửng cũng được gia tốc theo hướng này [8].

Lời cảm ơn: Công trình này được tài trợ bởi đề tài mã số VAST.ĐLT.06/15-16.

\section{TÀI LIỆU THAM KHẢO}

1. Wolanski, E., Nhan, N. H., and Spagnol, S., 1998. Sediment dynamics during low flow conditions in the Mekong River estuary, 
Vietnam. Journal of Coastal Research, 472-482.

2. Wolanski, E., Huan, N. N., Nhan, N. H., and Thuy, N. N., 1996. Fine-sediment dynamics in the Mekong River estuary, Vietnam. Estuarine, Coastal and Shelf Science, 43(5): 565-582.

3. Nguyễn Ngoc Thuy, 1982. Thủy triều đồng bằng sông Cửu Long và vùng biển kế cận. Báo cáo tại: Hội thảo Quốc tể về xâm nhập mặn ở ĐBSCL, tp. Hồ Chí Minh.

4. Wang, Z., Saito, Y., Hori, K., Kitamura, A., and Chen, Z., 2005. Yangtze offshore, China: highly laminated sediments from the transition zone between subaqueous delta and the continental shelf. Estuarine, Coastal and Shelf Science, 62(1): 161-168.

5. Nguyễn Ngoc Tiến, 2014. Nghiên cứu chế độ thủy động lực ven bờ biển của hệ thống sông Mê Kông. Tạp chí Khoa học và Công nghệ biển, 14(4): 310-319.

6. Nguyễn Ngoc Tiến, 2015. Ảnh hưởng của các yếu tố thủy động lực đến đặc điểm phân bố trầm tích lơ lửng vùng biển ven bờ sông Mê Kông. Tạp chí Khoa học và Công nghệ biển, 15(2): 150-158.

7. Zu, T., Gan, J., and Erofeeva, S. Y., 2008. Numerical study of the tide and tidal dynamics in the South China Sea. Deep Sea Research Part I: Oceanographic Research Papers, 55(2): 137-154.

8. Unverricht, D., Nguyen, T. C., Heinrich, C., Szczucinski, $\quad W$., Lahajnar, $N$. , and Stattegger, K., 2014. Suspended sediment dynamics during the inter-monsoon season in the subaqueous Mekong Delta and adjacent shelf, southern Vietnam. Journal of Asian Earth Sciences, 79, 509-519.

\title{
THE INITIAL RESULTS OF STUDYING THE SUSPENDED SEDIMENT DYNAMICS DURING THE FLOOD SEASON IN THE HAU RIVER MOUTH AREA
}

\author{
Nguyen Ngoc Tien ${ }^{1}$, Nguyen Trung Thanh ${ }^{1}$, Vu Hai Dang ${ }^{1}$, Vu Duy Vinh ${ }^{2}$ \\ ${ }^{1}$ Institute of Marine Geology and Geophysics-VAST \\ ${ }^{2}$ Institute of Marine Environment and Resources-VAST
}

\begin{abstract}
Land-ocean interactions in the coastal zone are severely influenced by tidal processces. In regions of high sediment discharge like the coast of Hau river estuary, these processes are even more significant when we analyse data in flood season (September) - which belongs to Agreement of Cooperation in Science and Technology between Vietnam and US (2013-2015) and project VAST-DLT.06/15-16 (2015-2016). Our goal is to investigate the sedimentation processes. Additionally, we investigated the influence of the tidal currents in relation to the suspended sediment. Salinity (PSU - Practical salinity unit), suspended sediment concentration (NTU - Nephelometric Turbidity Units) were measured by Compac-CTD (Depth temperature conductivity chlorophyll turbidity) and OBS-3A (Turbidity and Temperature Monitoring System) instruments. The results show that the suspended sediment concentration (SSC) correlate with tidal current velocities. The tidal current velocities are up to $60 \mathrm{~cm} / \mathrm{s}$ near the surface and $40 \mathrm{~cm} / \mathrm{s}$ near the bottom, increasing SSC in the water column at bottom layer (24 NTU) and decreasing SSC at surface layer (8 NTU). Processes of sediment transport and deposition in flood tide in flood season are influenced by tidal currents more significantly than those in dry season. This leads to an asymmetry of the tidal ellipses and the different deposition between seasons. The analytical results imply the influence of tide and tidal currents on SSC in the coast of Hau river estuary, hence, the spread, sea water and fresh water mixing processes have difference during tidal phases and seasons.
\end{abstract}

Keywords: Suspended sediment, salinity, sediment dynamics, Hau river. 